\title{
The Relationship between Favouritism Behaviours of Secondary School Administrators and Organizational Commitment of the Teachers ${ }^{*}$
}

\author{
Abidin Dağli ${ }^{1}$, Zuhal Akyol $^{1}$ \\ ${ }^{1}$ Dicle University, Turkey \\ Correspondence: Dicle University, Turkey.
}

Received: April 1, 2019

Accepted: May 5, 2019 Online Published: May 15, 2019

doi:10.11114/jets.v7i7.4191

URL: https://doi.org/10.11114/jets.v7i7.4191

\begin{abstract}
The aim of this study is to determine the relationship between the favouritism behaviours of secondary school administrators and organizational commitment of teachers. The research population consists of 3403 teachers from 64 secondary schools in the central district of Diyarbakir/Turkey in the academic year of 2016-2017. The data collection instrument was applied to randomly selected 376 teachers from 22 schools. "Favoutism in the School Management Scale", developed by Erdem and Meric (2012) and three dimensional "Organizational Commitment Scale", developed by Meyer, Allen and Smith (1993) and adapted into Turkish by Dağll, Elçiçek and Han (2017) were used in this research. The arithmetic mean, standard deviation were used in the analysis of data. The relationship between favoritism and organizational commitment behaviour was studied using Spearman Correlation Coefficient. Some important findings obtained in the research can be listed as follows: Teachers participated the overall mean of "Favouritism in the School Management Scale" at "sometimes" level $(\mathrm{M}=2.86)$. According to teachers' perceptions, the dimensions with the highest means are in order; (1) Planning ( $M=3,121$; Sometimes), (2) Coordination ( $M=2,961$; Sometimes), (3) Evaluation ( $M=2,368$; Sometimes) and (4) Organization ( $M=2,936$; Sometimes). Teachers participated the overall mean of "Organizational Commitment Scale" at "not sure" level. According to teachers' perceptions, the dimensions with the highest means related to organizational commitment are in order; (1) Affective commitment ( $M=3,07$; Neutral), (2) Continuance Commitment ( $M=2,79$; Neutral) and (3) Normative Commitment ( $M=2,63$; Neutral). In the study, a moderate level of negatively significant relationship was found between favouritism behaviours of school administrators and organizational commitment of teachers. $(r=-.359, \mathrm{p}<.01)$. The more favouritism behaviours of school administrators are, the less organizatioal commitment of teachers are.
\end{abstract}

Keywords: favouritism, favouritism in school management, commitment, organizational commitment

\section{Introduction}

In the globalization world, concept such as equality, transparancy accountability, rights and fairness have been very often pronounced in every aspect of life and the administrators who do not give importance to these concepts in their applications have been in the centre of the criticism. The administrators taking aforementioned concepts into consideration while carrying out management activities are mostly appreciated whereas the administrators who do not take the objective criteras such as competence and proficiency into account in their practices have been criticized on the grounds that they are favoring (Meric and Erdem, 2013: 468).

Favouritism is the choice of an individual or group with equal rights to other individuals or groups (Roy and Roy, 2004: 238). Favouritism is the tendency to deviate from rights and justice for the benefit of just a person or a group (Erdem, 2010: 1). It is favoring a person not because he or she is doing the best job but rather because of some extraneous feature-membership in a favored group, personal likes and dislikes, etc (Nadler and Schulman, 2006). It can also be defined as giving priority to friendship or kinship relations rather than qualitative ones in the selection of a specific staff (Oren, 2007: 84). Favouritism is giving primacy to kinship, friendship relations or political and religious partisanship into the appointment or promotion for the public services. It can also be defined as directing public resources in favor of political power and the electorate (Akozer, 2013:16).

\footnotetext{
*This study was formed and partially developed from Zuhal AKYOL's master thesis which was prepared under the guidance of Associate Professor Doctor Abidin Dağll.
} 
According to Kim (2004) favoritism, which is now a reality in most countries, demonstrates democracy underdevelopment and is one of the main reasons for lack of productivity (cited in Demaj, 2012: 24). The history of corruption is nearly as old as the history of the governments. Unfortunately, corruption has been encountered in every period of history and everywhere in the World. A Sumerian tablet dating back to 4000 B.C. at the Istanbul Archaelogical Museum, deciphered by Sumerologist Veysel Donbaz is accepted as the first document of bribery. In that tablet, called "Sumer School Days" a student who fails in the school is told. This student's parents want their child to be successful in his lessons. For this purpose, they invite the teacher to their homes and feed him, and give him a number of gifts. All the night continues in the same way in the written tablet. The answer of the question, "what happens afterwards?" is explained in the rest of the tablet and the unsuccessful student suddenly becomes the most successful of the class. What's more, this student is being made the chief of the class, that's to say he becomes the president of the class (Tarhan, Genckaya, Ergul, Ozsemerci and Ozbaran, 2006: 33).

When the reasons why people engage in favouritism behaviours and attitudes, material and spiritual profits of both the favoring and favored come to mind. The person favoring the others gets back the compensation of the favouritism in some way. This compensation can be in the form of acquiring income, prestige and power or being supported by the others (Ozkanan and Erdem, 2014: 181). As the person favored has a sense of gratitude towards the person who favors, he shows this in the form of respect, gratitude, attachment, loyalty, gift and bribe. In this way, the person who favors gains income, prestige and power and he strengthens his position. As for the person who is favored, he reaches temporary and instant opportunities and facilities (Aytac and İlhan, 2010: 63). Because of the fact that favouritism relations provoke inequality and cause to unfair practices, they have been reduced by some prohibitive rules. However, such applications are still quite common in almost every industry and give an institutionalized view (Aytac, 2010a: 5).

According to Zingales (2012), cronyism represses freedom of speech, eliminates the incentive to study and jeopardizes career opportunities. Favouritism leads to weakness for the favored ones, it also causes work loss and failure in terms of the business environment as success and talent are not taken into consideration.

Favouritism could be identified in one or more of the following ways (Ramanchander, 2011):

1. The superior spends too much time and socialises more with the favourite employee than any other employee in the organisation

2. The superior confides in the favourite employee and discusses all the confidential issues

3. The superior commends the favourite employee for even a small achievement that others are not praised for

4. The superior overlooks even the mistakes made by the favourite employee

5. The superior gives additional benefits and assistance for completion of the task to the favourite employee

6. The superior takes advises of the favourite employee without gauging the pros and cons even in issues relating to emoluments of other employees

7. Above all, the favourite employee enjoys more benefits like better office, added perquisites and benefits than others who are in the same position.

As the favouritism is a very comprehensive term, it has been dealt with in a wide variety of ways by the authors. For example, Ozkanan and Erdem (2014) took the favouritism into consideration in the forms of (1) nepotism, (2) cronyism, (3) partisanship, (4) service favouritism, (5) clientalism. Aydogan (2009) and Polat and Kazak (2014) divided favouritism into three as (1) nepotism, (2) cronyism and (3) patronage. Celik and Erdem (2012) categorised favouritism in two forms: (1) man-favoring and (2) service favouritism. Meric (2012) dealt with the types of favouritism in more detail than other authors. He took favourtisim under 6 titles. These are (1) nepotism, (2) cronyism, (3) partisanship, (4) service favouritism, (5) patronage and (6) sexual favouritism. In this study, the types of favouritism, which were suggested by Meric (2012) and thought to be common in public institutions, were discussed and described briefly below.

1. Nepotism: It is called nepotism to employ or promote persons who do not have the qualifications required by the job, regardless of factors such as skill, ability, success and level of education, just on the basis of kinship relationships (Ozler, Ergun-Ozler and Gumustekin-eren, 2007: 438; Dökumbilek, 2010: 44). Nepotism is the practice of unfairly giving the best jobs to members of your family when you are in a position of power (Longman, 2014: 1101). From an organizational perspective, nepotism can have several negative consequences. First, nepotism may result in reduced faitness perceptions. Second, perceived nepotism and cronyism may lead to increased job stress among organizational employees, for example, as a consequence of conflicts when dealing with underqualified employees that are hired because of nepotism. Third, nepotism is associated with lowered organizational satisfaction and commitment (Hooft and Stout, 2012: 77, 78). Patgett and Morris (2005) reported that people had lower organizational commitment 
when their supervisor was hired based on nepotism (cited in Hooft and Stout, 2012: 78).

2. Cronyism: Cronyism is one particular form of organizational politics, which is a much broader concept comprising varied political behaviours. Generally, cronyism is favouritism shown to associates without regard to their qualifications. Often, decisions are based on who is liked and not premised on merit. For example, an employee with a good performance record loses out on a promotion or pay increase because the person in charge favoured another person on the basis of friend-friend, informal relationship. Thus, merit takes a back seat in cronyism, as it is favouritism that determines who gets ahead (Khatri, Ya Wen, Fuei and Geok, 2008: 5). Cronyism is the favoring of public servants on the basis of peer-friendly relations instead of equality and merit in the recruitment of the work (Ozsemerci, 2003: 29). In "real" politics, cronyism is often used synonymously with corruption. The World Bank broadly defines corruption as "the abuse of public office for private gain" (Bottelier, 1998; cited in Khatri, Ya Wen, Fuei and Geok, 2008: 4). Cronyism is a similar concept to nepotism. The only difference between them is that nepotism is favoring of individuals from the same family and in the nepotism the person who is favored is brought to a position that he does not deserve because of his family ties, not thanks to his abilities (Ozkanan and Erdem, 2014: 190).

3. Political Favouritism (Partisanship): After the political parties come to power, they make a priviliged process to the voter groups supporting them and they provide unfair benefits to these groups. This situation is called political favourtism (Tarhan, Genckaya, Ergul, Ozsemerci and Ozbaran, 2006: 30; Ozkanan and Erdem, 2014: 192). The political parties that come to power would like to employ their supporters or political party members in public institutions and organizations. This practice that is very widespread in many countries not only damages neutrality but it is also the most important factor preventing effective and productive functioning of the public administration (Yıldırım, 2013: 359).

4. Service Favourtisim: In order to remain in power again, in the upcoming elections, the political power allocates budget allocations to its own sectorial regions in a way that maximizes its votes. As a result of this, budget resources will have been looted. With such a corruption, in the distribution of public resources, settlement areas and needs are not taken into account and services are taken to the political powers' own constituencies (Tarhan, Genckaya, Ergul, Ozsemerci and Ozbaran, 2006: 31). Yilmaz and Kilavuz (2002) evaluate service favouritism as type of political favouritism and define this favouritism type as allocating budget appropriations to the electoral district to maximize the power's votes.

5. Patronage: It can be defined as being supported or armored by someone in the upper position (Karakas and Cak, 2007: 78). When political parties, in the political process, dismiss "senior bureaucrats" working in public institutions and organizations and assign new people to these tasks based on the factors such as political loyalism, ideology, nepotism-kronism, this situation is called "patronage" in the literatüre (Tarhan, Genckaya, Ergul, Ozsemerci and Ozbaran, 2006: 31).

6. Sexual Favourtitism: Sexual favoritism occurs when a supervisor grants benefits and/or promotions to an employee with whom he or she is having a sexual and/or romantic relationship, and in turn denies these benefits and/or promotions to qualified third-party employees. Not only is such preferential treatment unfair, but it also may cause great harm to third-party employees, to the paramours, and to managers within the workplace. Regarding negative effects on third-party employees, one major concern associated with sexual favoritism is that employees are assessed according to their sexual conduct, rather than their work product. Favoritism may convey to employees that their sexuality, rather than their hard work or creativity, is the currency needed to gain benefits in the workplace. Third-party employees may feel threatened and uncomfortable as a result of this conduct. In addition, sexual favoritism may lead to lower office morale, as employees may become jealous and angry at officemates who use their sexuality to gain benefits (cited in Sheridan, 2007: 383, 384). In his opening speech in Parliament in 1994 former president Nelson Mandela said: "Freedom cannot be achieved unless women have been emancipated from all forms of oppression" (Prisloo, 2006: 305). One of the atrocities suffered by women and probably the most painful one is the sexual abuse they are subjected to. Sexual harassment constitutes a violation of the victims' personality rights and freedom legally as well as the impacts of their psychological and physical health on the social and economic life (Bakırc1, 2000).

On the other hand, school administrators are primarily responsible for realizing the aims of the schools, we call educational organizations. "School administrators should exhibit an attitude away from favouritism by being fair, objective and having an equal distance to the employees in the execution of the services of them. In the schools where the teachers having the perception that school administrators favor are working, education activities will also be negatively affected. If the teachers, who are the basic practitioners of the education, think that school administrators do not behave fairly in their practices, this affects both teachers' relationship with each other and their relationship with school administrators, negatively (Meric and Erdem, 2013)".

On the other hand, commitment is a mental or emotional state developed for a person, group, and theory or teaching (Bakırcioglu, 2012: 77). Organizational commitment requires adopting the organization whole heartedly, showing 
respect to its goals, rules, strategies, norms and cultures and it also requires supporting the organization (Eren, 2010: 555). Organizational commitment is also a psychological commitment to the environment in which the employee is employed (Becker, Billings, Eveleth and Gilbert, 1996: 464). There are two dominant conceptualizations of organizational commitment in sociological literature. There are an employee's loyalty towards the organization and an employee's intention to stay with the organization. Loyalty is an effective response to, and identification with, an organization based on, a sense of duty and responsibility (Muthuveloo and Che Rose, 2005: 1079). Many important contributions have been made by Allen and Meyer to the researches of organizational commitment. They define organizational commitment as a psychological state that binds the individual to the organization (i.e. makes turnover less likely) (Allen and Meyer, 1990: 14). At the same time, Allen and Meyer investigated organizational commitment under three dimensions: (1) Affective commitment, (2) continuance commitment, (3) normative commitment. These are briefly explained below.

1. Affective Commitment: It represents the identification of employees with their organizations, their affiliation with the organization, and their emotional commitment to the organization (Allen and Meyer, 1996: 253). The employees with affective attachment are emotionally attached to the organization, they have a great desire to contribute to the organization, they prefer to do less absenteeism, and they work harder (Mathieu and Zajac, 1990). Affective commitment develops from positive work experiences such $\mathrm{s}$ job satisfaction and organizational justice and it is associated with desirable outcomes such as higher levels of organizational citizenship and lower levels of withdrawal (being absent and late) (Guney, 2015: 290).

2. Continuance Commitment: It means that employees are aware of the costs that will arise if they leave their organization (Allen and Meyer, 1996: 253). The main reason for the emergence of continuance commitment is that staying in the organization for the individual brings a profit to himself on the other hand leaving work causes him harm. The second reason is that there are no business alternatives (Ozkalp and Kırel, 2013: 671).

3. Normative Commitment: It expresses the commitment of employees towards the organization as a result of feeling of necessity (Allen and Meyer, 1996: 253). Normative commitment reflects the commitment of the employees to stay in the organization. Individuals' commitment to the organization helps them demonstrate certain behavioural actions, not because they are asked to act in this way for personal benefits, but because they believe that their actions are correct and moral (Balay, 2014: 28). An important way to create normative commitment in organizations is to make employees feel indebted to the organization they work with (Ozkalp and Kirel, 2013: 672).

When three forms of commitment increase, employees decide to remain in the organization; However, the motivation to remain in the first depends on the demand, the requirement in the second and the obligation in the third (Balay, 2014: 28). On the other hand, according to Katz and Kahn (1977: 375, 438), it is not enough for the employees in an organization to be just physically involved in the organization; they should also be psychologically integrated with the system. Because of that, they say that in the schools, the basic goal of which is to train and convert people, employees are required to be willing do more than job descriptions. In this sense, teachers need organizational commitment to work more self-sacrificing towards the school and the students they work for (Balay, 2014: 5). Researchers have highlighted three commitments of the teachers regarding the school. These are the willingness to make efforts for school, the willingness to continue to work at school, and the acceptance of the educational goals and values of the school. Commitment to teaching as another commitment requires three conditions. These are the persistence of the teacher to make a difference in teaching, the expectation of the students about learning, the willingness to make the necessary effort to realize the teaching (Weber, 1997: 269; cited in Balay, 2014: 127).

In general, the commitment of the teachers to their schools can be increased by taking following issues into consideration (Daglı and Gencdal, 2018: 166): School administrators; (1) should convince the school teachers that they act on behalf of the school's employees. (2) Should have a constant sense of appreciation for each other with teachers. (3) Should take precautions to reduce job stress. (4) Should identify teachers who show outstanding achievement and ensure that they are rewarded by the higher authorities. (5) Should create an appropriate climate for learning. (6) Should value teachers and market hem involve with the issues that concern them. (7) Should strive to create a high level of internal motivation. (8) Should increase knowledge of the teachers by informing them about developing technology and developments. (9) Should establish a regular and disciplined environment. (10) Should provide suitable physical conditions. (11) Should provide the sources related to the education in place and on time. (12) Should show effort to provide a suitable course load for teachers.

Organizational commitment has become one of the most researched issues in recent years. One reason why organizational commitment is being researched so much is that its impact is associated with job outcomes such as absenteeism, performance, motivation and dismissal behaviours. Therefore, all organizations would like to increase the level of commitment of their employees. It can be said that employees with a high commitment to the organization have made 
extra efforts in fulfilling their duties and achieving organizational goals, and that such employees have positive relations with the organization and continue their membership for a longer period of time (Daglı and Gencdal, 2018). However, when the school administrators, included in the scope of public officials provide benefits for their own sake, relatives or third persons by using their duties, titles and powers and make nepotism, clientalism, political favouritism or any kind of favouritism, this will negatively affect organizational commitment of the teachers called as human-bred engineers.

Some similar studies have been conducted directly and indirectly in Turkey and abroad on the favouritism behaviours of school administrators. For example; some studies have been made by Aydogan (2008, 2009, 2012), Meric (2012), Polat and Kazak (2014), Karahan and Yılmaz (2014), Aydın (2015), Argon (2015), Gecer (2015), Salc1 (2015), Karademir (2016), Okcu and Ucar (2016) in Turkey; and in other countries, some research have been made by Pounder and Blase (1988), Abdalla, Magharabi and Ragged (1998), Laker and Williams (2003), Garicano, Palacios-Huerto and Prendergast (2005), Demaj (2012), Chandler (2012) and Moharib (2013). The most similar researches and related findings from these researches are summarized below: Aydogan (2009) tried to determine if there was favouritism in the Turkish education system. According to the results of the survey, teachers expressed that managers behaved in favouritism, albeit in part, on the basis of provincial and school basis. Aydogan made a research to determine if there was favouritism in Turkish universities, if so, what the type of favouritism existed and to reflect the view of the faculty members on the reasons of favouritism in 2012. In this research, it was determined that favouritism existed in the appointment of dean, manager and head of the department, in the selection of teaching staff for academic activities, in the provision of teaching materials to acuties and universities, in the lack of effective communication with some of the teaching staff, in the opening of new departments/in the establishment of new units and in the formation of the faculty committee. Meric (2012) conducted a research based on the teachers' perceptions of whether school administrators in public primary schools affiliated to the Ministry of National Education are favoring in their practices or not. In the survey, it was found out that school administrators rarely favored in their practices. Polat and Kazak (2014) tried to determine the relationship between the favouritism attitudes and behaviours of school administrators and teachers' perceptions regarding the organizational justice in their study. In this study, it was determined that there was a meaningful and negative relationship between the favouritism behaviours and attitudes of school administrators and teachers' perceptions regarding organizational justice. In a study conducted by Karahan and Y1lmaz (2014) it was concluded that there was a decrease in the commitment levels of the employees to the organization as the frequency of exposure to the nepotism increased.

Aydin (2015) made a research in order to reveal the perceptions of teachers about organizational silence, favourtisim in school management and self-efficacy and explained the relationship between these variables. As a result of the research, it was revealed that teachers' perception of favouritism in school management was low. Argon (2015) in her research tried to determine favouritism behaviours of primary school administrators in accordance with teacher opinions. According to findings of the research, the administrators favoured about the issues such as politics, co-friends, relatives, gender, union, award-punishment, appointment and their own interests. Gecer (2015) examined the relationship between the level of favourtisim and organizational support perception of teachers working in high schools in his research. As a result of the research, it was concluded that the teachers' perceptions of favouritism were at "moderate level". Salc1 (2015) concluded that the commitment of the employees to their organizations decreased as the behaviour of favouritism increased in his research, called "The effect of nepotism on organizational commitment; a field research in tourism businesses of Mersin province". Karademir (2016), in his study, examined the relationship between favouritism perceptions of secondary school teachers in school management and organizational cynicism. As a result of the study, it was determined that the teachers' perception of favouritism in school management was low. Okcu and Ucar (2016), in their studies, tried to determine the impact of favouritism attitudes and behaviours of school administrators on the teachers' organizational commitment. As a consequence of the study, it was determined that administrators' attitudes and behaviour were at low level according to teachers' perceptions and it was also found out that there was a moderate and negative level relationship between administrators' favourtisim attitudes and behaviours and teachers' organizational commitment. In their research, Pounder and Blase (1988) tried to determine what the policies in the school mean to the teachers. More than $1 / 3$ of the teachers expressed that school administrators were favoring and more than $60 \%$ of the teachers revealed that favouritism made by the managers negatively affected their performance in the class. Laker and Williams (2003) made a research called "Nepotism's effect on employee satisfaction and organizational commitment: An empirical study". The result of the study showed that employees displayed unsatisfying attitudes when they felt favouritism and injustice. Demaj (2012) made a research on nepotism, favouritism and cronyism and their impact on organizational trust and commitment; the service sector case in Albania. According to the findings of the study, nepotism has negative effects on employees' organizational trust and commitment.

As we have seen, there is no direct sufficient number of researches related to this research in Turkey or in some other countries outside Turkey on the relationship between school administrators' favouritism behaviours based on teachers' 
perceptions and their organizational commitment. Although the relationship between the teachers' organizational commitment and favouritism behaviours of school administrators is important in terms of the essence of education, the fact that there is no direct sufficient number of research related to the subject makes it necessary. On the other hand, in the literature survey carried out, it was concluded that no research was conducted on the relationship between the teachers' organizational commitment and favourtisim behaviours of school administrators based on the perceptions of the teachers in secondary schools in Diyarbakir province. And in this study, based on the perceptions of teachers in public secondary schools in Diyarbakir province, the relationship between teachers' organizational commitment and favourtitism behaviours of secondary school administrators was tried to be investigated. It is hoped that the research will shed light on teachers, administrators in the survey and the researchers who will make a study on this topic.

\subsection{The Purpose of the Research}

The purpose of this study is to determine the relationship between the teachers' organizational commitment and favourtisim behaviours of school administrators in public secondary schools. For this purpose, the following questions were asked:

1. What are the perceptions of the teachers in secondary schools about the favouritism behaviours of school administrators?

2. What are the perceptions of the teachers in secondary schools about organizational commitment?

3. Is there a significant correlation between the perceptions of teachers in secondary schools regarding favouritism behaviours of school administrators and the perceptions of organizational commitment behaviour?

\section{Method}

This section focuses respectively on the model of the research, the universe and the sample, data collection tool and the analysis of the data.

\subsection{The Model of the Research}

In this study, survey and relational survey model was used. "In the survey model, the individual or object of the research is tried to be defined in their own conditions and as they are. In the relational survey model, we try to determine the degree or presence of change between two or more variables (Karasar, 2006: 77, 81)".

\subsection{The Population and the Sample}

The Population of this research is composed of teachers working in secondary schools in Diyarbakir/Turkey central districts (Sur, Yenisehir, Kayapınar, Baglar) in 2016-2017 academic year. There are 64 secondary schools in Diyarbakir central districts in total and 3403 teachers are employed in these schools. The random method of sampling methods was used in the study. "In the random method, objects are chosen not at one point of the universe but all over the place. Everyone has equal chance to be chosen. It is impossible to predict who will be chosen beforehand (Kaptan, 1991: 120)". The sample of the study consists of 22 schools chosen from the universe by random method and 376 teachers are employed in these schools. $84,9 \%$ of the teachers who attended the survey had undergraduate degree and $15,1 \%$ of them had graduate degree. Also, 41,8\% of them were female, $58,2 \%$ of them were male; $73,1 \%$ of them were married and $26,9 \%$ of them were single. $26,3 \%$ of the teachers had seniority between 1 and 5 years, $19,7 \%$ of them had seniority between 6 and 10 years, 30,1\% of them had seniority between 11 and 15 years, 14,1\% of them had seniority between 16 and 20 years and $9,8 \%$ of them had seniority 21 years and over. $17 \%$ of the schools where teachers work were small schools, $38,8 \%$ of them were middle-sized schools and 49,2 \%of them were big schools. $60,1 \%$ of teachers had union membership, and the rest of the teachers, 39,9\%of them, didn't have any union membership.

\subsection{Data Collection Tools}

The data of the study were obtained using the scale of "Favouritism in School Management" and "Organizational Commitment". The information about data collection tools of the research are summarized below.

1. Favouritism in School Management Scale: In this study, "Favoritism in School Management Scale" which was developed by Erdem and Meric (2012), the validity and reliability of which were determined, which was applied on the teachers employed in many public schools was used as a scale. The scale consists of 4 dimensions and 25 items. The first dimension "planning" consists of 4 items $(1,2,3,4)$, the second dimension "organization" consists of 7 items $(5,6$, $7,8,9,10,11)$, the third dimension " coordination" consists of 5 items $(12,13,14,15,16)$ and the fourth dimension "evaluation" consists of 9 items. The answers to the questions were rated as "always (5)", "usually (4)", "sometimes (3)", "rarely (2)" and "never (1)". While interpreting averages, the average values between 1.00 and 1.79 were accepted at "never" degree, the average values between 1.80 and 2.59 were accepted at "rarely" degree, the average values between 2.60 and 3.39 were accepted at "sometimes" degree, the average values between 3.40 and 4.19 were accepted at "usually" degree and the average values between 4.20 and 5.00 were accepted at "always" degree. 
According to analysis made by Erdem and Meric (2012), the first factor of the scale describes 20, $963 \%$ of total variance, the second factor describes $20,579 \%$ of it, the third factor describes $19,723 \%$ of it and the last factor describes $11,798 \%$ of it. All factors in total explain favouritism by $73 \%$. It has been observed that the scale items have a minimum load value of 0,416 and maximum load value of 0,852 . Cronbach's alpha, a scale reliability test, was found to be 0.962 at the scale. The total correlations of items on the scale range from 0.487 to 0.764 .

In this study, Cronbach's alpha internal consistency coefficients belonging to the "Favouritism in School Management Scale" were determined for "planning", 91; for "organization",95; for "coordination" ,93; for "evaluation" ,94 and, 97 for the whole scale.

2. The Organizational Commitment Scale: In this study, the organizational commitment scale, developed by Meyer, Allen and Smith, and adapted into Turkish by Dagli, Elcicek and Han was used. This measurement tool used in the research consists of 3 dimensions and 18 items. The first dimension, "affective commitment" consists of 6 items (1, $2,3,4,5,6)$, the second dimension, "continuance commitment" consists of 6 items $(7,8,9,10,11,12)$ and the last dimension "normative commitment" consists of 6 items again $(13,14,15,16,17,18)$. The answers to the questions were rated as "certainly disagree (1)","I disagree (2)", "I am neutral (3)", "I agree (4)", "I totally agree (5)". While interpreting averages, the average values between 1.00 and 1.79 were accepted at "I certainly disagree"; the average values between 1.80 and 2.59 were accepted at "I disagree"; the average values between 2.60 and 3.39 were accepted at "I am not sure"; the average values between 3.40 and 4.19 were accepted at "I agree" and the average values between 4.20 and 5.00 were accepted at "I totally agree". In addition, items 3,4 and 5 in affective commitment and 13th item in normative commitment are designed as reverse items. Therefore, the points of these items were made in reverse. According to analysis made by Dagli, Elcicek and Han (2018), the first factor of the scale describes $35.418 \%$ of total variance, the second factor of the scale describes $9.177 \%$ of it and the third scale describes $8.124 \%$ of the total variance. All factors explain organizational commitment in total by $52.719 \%$. Factor loads for measurement are between .33 and .80. All items other than 13.item (has .33 factor load) have a factor load over .40. When we look at the Cronbach's alpha values, we see .80 at first dimension, .73 at second dimension, .80 at third dimension and .88 was determined at the total of the scale. It was determined that a single item did not meet .30 sub-limit criteria regarding the total correlation values for the measure (item 12). However, this item was also decided to stay on the scale with the opinion of the expert since it was at the limit of .20. The total correlation values of the items, except 12th item, range from 0.32 to 0.73 .

In this study, Cronbach's alpha internal consistency coefficients belonging to organizational commitment scale were determined as ,81 for affective commitment; 75 for continuance commitment; ,80 for normative commitment and ,89 for the whole scale.

\subsection{The Analysis of Data}

The mean and standard deviation coefficient were used to determine the distribution of teachers' favouritism and organizational commitment scores for the responses of first and second sub-objectives in the analysis of data. In the third sub-objective, Spearman's sequential correlation was used to examine the relationship between favouritism and organizational commitment scores. Correlation is a statistical process that shows the amount and direction of the relationship between two data sets (Can, 2014: 347). Correlation coefficient both presses a meaning and it gives information about whether its direction is positive or negative. The correlation coefficient is between -1 and +1 . When the correlation coefficient is zero, it signifies that there is no relationship between the measured data (Taylor, 1990: 36). As the correlation coefficient gets closer to +1 , it underlies that the relationship is strengthened in the positive direction and as the correlation coefficient gets closer to -1, the relationship is strengthened in the negative direction. "When the correlation coefficient is between 0.70 and 1.00 , it is defined as high-level relationship; if it is between 0.70 and 0.30 , it is medium-level relationship and if it is between 0.30 and 0.00 , it is defined as low-level relationship (Buyukozturk, 2010: 32)".

\section{Results}

In this section, the answers to the questions (1) What are the perceptions of the teachers in secondary schools about the favouritism behaviours of school administrators?(2) What are the perceptions of the teachers in secondary schools about organizational commitment? and (3) Is there a significant correlation between the perceptions of teachers in secondary schools regarding favouritism behaviours of school administrators and the perceptions of organizational commitment behaviour? are sought respectively.

\subsection{Findings Related to the Perceptions of Teachers About Favouritism Behaviours of School Administrators}

The mean, standard deviation scores and levels of the teachers' perceptions about the behaviour of the school administrators in terms of dimension and scale are presented on Table-1. 
Table 1. Findings related to the perceptions of teachers about favouritism behaviours of school administrators

\begin{tabular}{llll}
\hline Dimension & M & Sd & Level \\
\hline Planning & 3,121 & 1,143 & Sometimes \\
\hline Organization & 2,936 & 1,105 & Sometimes \\
\hline Coordination & 2,961 & 1,221 & Sometimes \\
\hline Evaluation & 2,638 & 1,161 & Sometimes \\
\hline Average of all scale & 2,863 & 1.055 & Sometimes
\end{tabular}

As shown on Table 1, the highest mean of teachers' perceptions about the favouritism behaviour of the school administrators is determined in the "planning" dimension and the lowest mean is determined in the "evaluation" dimension.

\subsection{Findings Related to Organizational Commitment Perceptions of the Teacher}

The mean, standard deviation scores and levels of teachers' perceptions about organizational commitment in terms of dimension and scale are presented on Table- 2

Table 2. Findings Related to Organizational Commitment Perceptions of the Teacher

\begin{tabular}{llll}
\hline Dimension & M & Sd & Level \\
\hline Affective Commitment & 3,07 & 1.01 & Not sure \\
\hline Continuance Commitment & 2,79 & .65 & Not sure \\
\hline Normative Commitment & 2,63 & .96 & Not sure \\
\hline Average of all scale & $\mathbf{2 . 8 9}$ & $\mathbf{1 . 3 1}$ & Not sure \\
\hline
\end{tabular}

As shown on Table-2, the highest mean of teachers' perceptions about organizational commitment is determined in the "affective commitment" dimension and the lowest mean is determined in the "normative commitment" dimension.

3.3 Findings on the Relationship between the Perceptions of Teachers about the Favouritism Behaviours of School Administrators and Organizational Commitment

Findings on the relationship between the perceptions of teachers about the favouritism behaviours of school administrators and organizational commitment are presented on Table-3.

Table3.Findings on the Relationship between the Perceptions of Teachers about the Favouritism Behaviours of School Administrators and Organizational Commitment

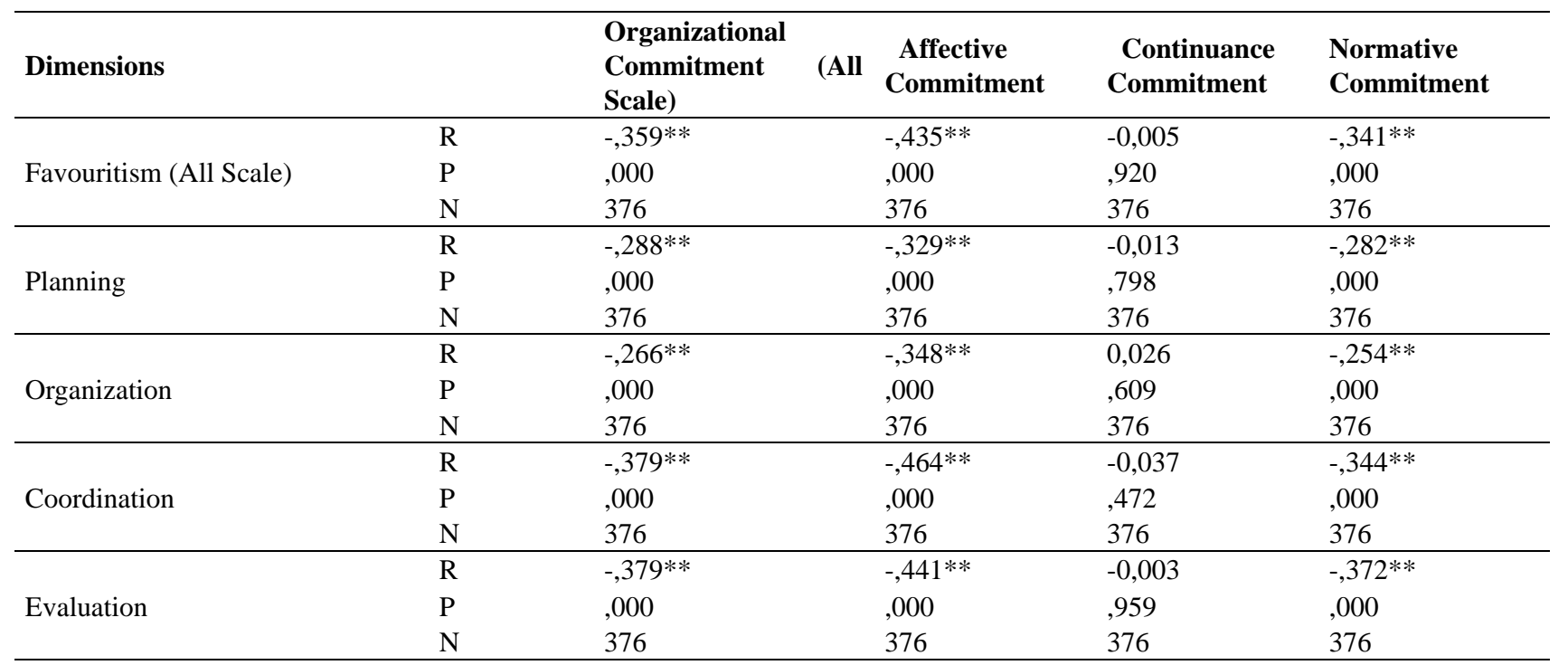

$* * \mathrm{p}<.01$

When Table- 3 is examined, there is a negative directional and moderate level relationship between the favouritism and affective and normative dimensions of organizational commitment $(\mathrm{r}=-.435, \mathrm{p}<.01) ;(\mathrm{r}=-.341, \mathrm{p}<.01)$. But there is no relationship between favouritism and continuance commitment of organizational commitment $(r=-.005, p>.01)$.

When the relationship between the subdimensions of favourtism and subdimensions of organizational commitment is examined, it is recognized that there is a negative directional and low-level relationship between planning 
sub-dimension of favouritism and organizational commitment $(\mathrm{r}=-.288, \mathrm{p}<.01)$. There is also a negative directional and moderate level relationship between planning and affective commitment $(r=-.329, p<.01)$. But a negative directional and low-level relationship between planning and normative commitment was determined $(\mathrm{r}=-.282, \mathrm{p}<.01)$. In addition, there is no relationship between planning and continuance commitment $(\mathrm{r}=-.013, \mathrm{p}>.01)$. There is a negative directional and low-level relationship between organization sub-dimension of favouritism and organizational commitment $(\mathrm{r}=-.266, \mathrm{p}<.01)$.There is also a negative directional and moderate level relationship between organization and affective commitment $(\mathrm{r}=-.348, \mathrm{p}<.01)$. But a negative directional and low-level relationship between organization and normative commitment was determined $(\mathrm{r}=-.254, \mathrm{p}<.01)$. However, there is no relationship between organization and continuance commitment $(\mathrm{r}=.026, \mathrm{p}>.01)$. There is a negative directional and moderate-level relationship between coordination sub-dimension of favouritism and organizational commitment $(\mathrm{r}=-.379, \mathrm{p}<.01)$. Also, a moderate-level and a negative directional relationship exists between coordination and affective and normative commitment $(\mathrm{r}=-.464, \mathrm{p}$ $<.01),(\mathrm{r}=-.344, \mathrm{p}<.01)$. But, a significant relationship between coordination and continuance commitment wasn't determined $(\mathrm{r}=-.037, \mathrm{p}>.01)$. There is a negative directional and moderate-level relationship between evaluation sub-dimension of favouritism and organizational commitment $(\mathrm{r}=-.379, \mathrm{p}<.01)$. At the same time, a moderate-level and a negative directional relationship exists between evaluation and affective and normative commitment. $(\mathrm{r}=-.441, \mathrm{p}<.01)$, $(\mathrm{r}=-.372, \mathrm{p}<.01)$. However, a significant relationship between evaluation and continuance commitment wasn't determined $(\mathrm{r}=-.003, \mathrm{p}>.01)$.

On the other hand, it was found out that there was a negative directional and moderate level relationship between the teachers' perceptions regarding favouritism behaviours of school administrators and organizational commitment $(\mathrm{r}=-359$, $\mathrm{p}<.01)$.

\section{Discussion}

In this section, the results of the research were interpreted and discussed in relation to the results other studies in the field of research.

In this study, "the relationship between the perceptions of teachers in public secondary schools regarding favouritism behaviours of their school administrators and their organizational commitment perceptions" was investigated. In the study, teachers participated total average of the favouritism scale at "sometimes" level. In a study conducted by Meric (2012), according to teacher perceptions, school administrators favored at rarely level. In the research conducted by Polat and Kazak (2014), favouritism behaviours of school administrators were determined at a low-level according to teachers' perceptions. In a study conducted by Karademir (2016), it was determined that school administrators favored at low-level according to teachers' perceptions. It can be said that the results of these researches are close to each other and support existing research findings. Favouritism is a form of twisted relationship established by close relationship networks (Aytac, 2010b). When it is believed that favouritism exists in an organization, it may lead to a number of negative consequences for the employees of the organization. It can decrease the performance of the employees, reduce organizational commitment, increase stress and cause business dissatisfaction (Celik and Erdem, 2012: 28). For this reason, the problem of favouritism in organizations should be solved at the first stage as Ramanchander (2011) said. Otherwise, this condition may result in reactions such as other employees' disliking workplace, keeping information, frequent discussions in the business environment, lack of confidence, having an attitude against the boss or the person who is favored.

The average of the teachers' perceptions involved in the study was determined at "sometimes" level for the dimensions of "planning $(M=3,12)$ ", "organization $(M=2,93)$ ", "coordination $(M=2,96)$ " and "evaluation $(M=2,63)$ ". As it is seen, the highest average related to favouritism can be said to be in the "planning" dimension. In other words, it can be said that school administrators behave a little more favorably when they prepare teachers' weekly and guard schedules, plan their class and lesson distribution. On the other hand, the lowest average on the basis of dimension was determined in the "evaluation" dimension. In other words, according to teachers' perceptions, it was determined that school administrators behaved favorably the least at the following issues: the unions of which teachers are members, their gender, political opinions, the vocational seniority, their country, branches, giving performance evaluation mark to the teachers, the offer of the teachers to be rewarded, the appointment of the teachers who neglect their duties. In a survey conducted by Aydin (2015), teachers stated that favouritism behaviours of school administrators were at low- level at the planning and organization $(\mathrm{M}=2,11)$, coordination $(\mathrm{M}=2,10)$ and evaluation $(\mathrm{M}=1,99)$ dimensions. Also in the related research, the highest mean was in the planning, the lowest mean was in the evaluation dimensions. The findings of this study support the current research. It is important to know which motivations lie under favouritism relations and the dissemination of them. The existence of different groups, various interest groups and different types belonging matrixes in the society agitates for the emergence of discrimination, inequality or injustice. Different groups take the situation of marginalizing, negative or even hostile attitude against each other and they enter into a poignant attitude by making a distinction as "we" and "they". Not being from "us", being from outside group, community, tribe, ..etc pushes 
us to be insensitive to the rights of other groups, even makes us opposed to them (Aytac and İlhan, 2010: 70).

The average of the teachers' perceptions regarding organizational commitment was determined at the level of "neutral" for the whole scale. This finding can be interpreted as the lack of awareness about the problems in case of leaving the organization, obligation to continue employment with the school and feelings of responsibilities regarding identification with the organization and participation into the it. On the other hand, in a survey carried out by Dagli and Gencdal (2018), teachers' perceptions of organizational commitment were determined at the level of "neutral" for the whole scale.

In the present study, it was determined that the highest average in terms of dimension was in "affective commitment" and the lowest average was in "normative commitment". In the studies carried out by Dagli and Gencdal (2018), Bozkurt ad Yurt (2013), Boylu, Pelit and Gucer (2007), the highest average was determined in "affective commitment" and the lowest average was in "normative commitment". As a matter of fact, the most desired situation regarding the importance of these dimensions in the relevant literature about organizational commitment is the high affective commitment of the employees (Brown, 2003: 41; Akt. Boylu, Pelit and Gocer, 2007). According to Afsar (2011: 10), individuals with high affective commitment remain in the organization as they wish and they are willing to make great efforts for the interests of the organization. Therefore, affective commitment is the type of commitment that is the most desirable one in organizations and that is required to be instilled to employees. In the present study, continuance commitment has the highest average after the affective commitment. According to Afsar (2011: 10), individuals with a high continuance commitment consider it necessary to stay in the organization so as to avoid financial and/ or other losses and that is an undesirable type of commitment for organizations. In the present study, the lowest mean was found to be in the normative commitment. If employees perceive that their organizations make important investments for them, they can have a sense of normative commitment to the organization in order to pay for this investment. For example, suppose that the organization sends some of its employees abroad for 1-2 years to increase their knowledge and skills. These employees may feel a sense of normative commitment as a debt of gratitude to their organizations that have provided support throughout their overseas training. They can be willing to stay in the organization as a member of it with the logic "how I can leave my organization that has given so much effort to me" (Bakan, 2011: 116).

The relationship between favouritism and sub-dimensions of organizational commitment was examined, there was a moderate and negative directional relationship with affective normative commitment $(\mathrm{r}=-.435, \mathrm{p}<.01) ;(\mathrm{r}=-.341, \mathrm{p}$ $<.01)$.But there was no relationship between favouritism and continuance commitment $(\mathrm{r}=-.005, \mathrm{p}>.01)$. Affective commitment is the commitment that workers feel at the rate in which they adopt their organizations' values, goals and target (Bayram, 2005: 132). The fact that an employee has an affective commitment to the organization is shown as the psychological commitment to the organization and the identification to the organization (Fields, 2002: 44). In this context, the negative impact of school administrators favouritism behaviours on teachers will stop the school from realizing its goals and reduces teachers' performances. On the other hand, in the normative commitment, the individual believes that he has a responsibility and liabilityto continue working in the organization. He feels that it is a duty to work in the organization and feels that it is right to stay in the organization or to be committed to the organization. Forthis reason, he feels compelled to stay in the organization and continue his membership (Allen and Meyer, 1990; Meyer et al, 2001). As in the affective commitment, in this dimension, when teachers are negatively affected by the favouritism behaviours of school administrators, this situation gives damage to teachers' loyalty to schools. As to continuance commitment, it is a dimension of a person's desire to stay in the organization. When the individual in this dimension continues to remain in the organization, he goes to an evaluation between the things it will gain to him and the things he will lose when he leaves the organization and he decides accordingly.

While there was a moderate and negative directional relationship between planning subdimension of favouritism and affective commitment and also there was a low and negative directional relationship between planning and normative commitment $(\mathrm{r}=-.329, \mathrm{p}<.01),(\mathrm{r}=-.282, \mathrm{p}<.01)$, there was no significant relationship between planning and continuance commitment $(\mathrm{r}=-.013, \mathrm{p}>$.01).In other words, if school principals favor while preparing weekly course and guarding schedules and planning the class and course delivery, this situation leads to a negative relationship with organizational commitment. This negative situation undermines teachers' adoption of their school values, goals and objectives, and their staying as part of their school. It reduces teachers' positive attitude towards work and negatively affects additional effort. On the other hand, it also weakens the sense of gratitude for teachers' schools.

While there was a moderate and negative directional relationship between organization subdimension of favouritism and affective commitment and also there was a low and negative directional relationship between organization and normative commitment $(\mathrm{r}=-.348, \mathrm{p}<.01),(\mathrm{r}=-.254, \mathrm{p}<.01)$, there was no significant relationship between organization and continuance commitment $(\mathrm{r}=.026, \mathrm{p}>.01)$. Namely, when school principals favor on the topics such as assigning teachers about social club work on specific day weeks/ to school boards, work division between teachers, giving teachers additional duties related to education and training, appointing teachers who will participate in the activities to 
be held at the school, in the distribution of tasks assignments (in terms of workload), this situation negatively affects teachers' organizational commitment.

While there was a moderate and negative directional relationship between coordination subdimension of favouritism and affective commitment and also there was a moderate and negative directional relationship between coordination and normative commitment $(\mathrm{r}=-.464, \mathrm{p}<.01),(\mathrm{r}=-.344, \mathrm{p}<.01)$, there was no significant relationship between coordination and continuance commitment $(\mathrm{r}=-.037, \mathrm{p}>.01)$. That is to say, when school principals favor on the topics such as teachers' violation of the rules (appearance, not attending the ceremonies,..etc), teachers in or out of the classroom on time or late, among teachers who do not perform their duties properly, allowing teachers, taking teachers' complaints into account, ...etc, teachers will agree that school administrators do not treat themselves fairly or equally and this situation reduces their commitment to the school.

While there was a moderate and negative directional relationship between evaluation subdimension of favouritism and affective commitment and also there was a moderate and negative directional relationship between evaluation and normative commitment $(\mathrm{r}=-.441, \mathrm{p}<.01),(\mathrm{r}=-.372, \mathrm{p}<.01)$, there was no significant relationship between evaluation and continuance commitment as seen in all the other dimensions $(r=-.003, p>.01)$.In other words, when school principals exhibit the behaviour of favouritism on the topics such as the unions teachers are member of, genders of the teachers, political views of them, their vocational seniority, countries, barnches, offer of the teachers to be rewarded, punishment of teachers disrupting their duties, this situation reduces their commitment to the school.

In the study, it was determined that there was a moderate and negative relationship between school administrators' favouritism behaviours and teachers' organizational commitment $(r=-.359, \mathrm{p}<.01)$. It was also determined that teachers' organizational commitment behaviour decreased as school administrators' favouritism behaviours increased. However, in a study conducted by Sezici and Yıldiz (2017), it was found out that organizational cronyism had a negative and significant relationship with organizational commitment. In a study conducted by Okcu and Ucar (2016), based on teachers' perceptions, it was determined that there was a negative and moderate relationship between the administrators' favouritism attitudes and behaviours and teachers' organizational commitment. In the study of Salc1 (2015) called, "the effect of nepotism on organizational commitment; a field research in tourism businesses of Mersin province", it was concluded that the loyalty of the employees to their organization decreased as the behaviour of favouritism increased. In another study conducted by Karakan and Yilmaz (2014), it was concluded that there was a decrease in the loyalty levels of the employees to the organization as the frequency of exposure to nepotism practices increased. The findings of these studies show parallelism with the present study findings. In the favouritism, when the employees feel different treatment, they can quit the work. This results in cost and human resources loss stem from staff change (Milgram and Roberts, 1988; extracted by Prendergast and Topel, 1996: 959). Working under the orders of an incompetent person for an employee who is subject to favouritism is a very annoying situation, and in particular when the wage system is injustice, this leads to the employees to break out of the organization (Bute, 2009: 737). The majority of teachers suggested that the practice of favouritism by principals lowered their motivation and morale/satisfaction, limited their opportunities for professional growth and advancement, constrained their sense of control and effort in classroom preparation, and reduced their interest and time commitment to extracurricular activities as well as routine school duties and responsibilities (Pounder and Blase, 1988). On the other hand, favouritism behaviours of school principals undermine the sense of justice among teachers at school and cause getting away from work, absence, low loyalty to work and organization, having a distance towards work and work stress. Nevertheless, job satisfaction and organizational trust negatively affects the morale and organizational commitment and there is a conflict between the teachers who are favored and other teachers. Briefly, teachers who think that their school administration practises favoritism and have a low commitment to their schools because of that with probably just dream of some things, and they will not be able to put them into effect.

\section{Recommendations}

As a result of the research, teachers think that favouritim exists in their schools at "sometimes" level and this is quite high for schools that we call educational organizations. Efforts must be made to reduce this level to "never" level. To do this, serious criteria should be brought for executive training, choosing administrator, appointment, promotion and evaluation (finishing post graduation and $\mathrm{PhD}$ programme on education management, etc). The provincial and District National Education Directorates of which the school directorates are affiliated should organize questionnaires to teachers from time to time to detect whether school principals are favoring or not and according to the results of these surveys, there should be one-to-one interviews with school administrators when it is necessary.

In the survey, it was found out that there was a moderate and negative directional relationship between favouritism behaviours of school administrators and teachers' organizational commitment. It was also determined that as favouritism behaviors increased, organizational commitment of the teachers decreased. Therefore, a transparent 
understanding of management that does not ignore values such as justice, equality in which communication channels are open will increase teachers' confidence and loyalty towards their schools. For this purpose, teachers and school administrators should be informed about the damages of favouritism for schools and the importance of organizational commitment through in-service training. As Rmanchander (2011) said, the problem of favouritism in organizations should be solved at the very first stage. Otherwise, this may result in reactions such as disliking workplace, keeping information, frequent discussions in the workplace, distrust, having an attitude against the boss or the favored employee, ..etc.

On the other hand, the situation at the national level can be explained by conducting nationwide research on the subject. Research can be done by comparing public and private primary schools. Similar research can be carried out at universities.

\section{References}

Abdalla, H. F., Maghrabi, A. S., \& Raggad, B. G. (1998). Assessing the perceptions of human resource managers toward nepotism: A cross-cultural study.International Journal of Manpower, 19(8), 554-570. https://doi.org/10.1108/01437729810242235

Afşar, S. T. (2011). Çalışmayaşam kalitesinin örgütsel bağlllık düzeyi üzerindeki etkisi: devlet ve vakıf üniversitelerinde çalışan akademisyenler üzerine nicel bir araştırma (The effect of working life quality on organizational commitment: a quantitative research on academicians working at state and foundation universities) (Unpublished $\mathrm{PhD}$ dissertation). Hacettepe University Institute of Social Sciences, Ankara.

Aközer, M. (2003). Kamuoyu gözüyle kamuda yolsuzluk.(Corruption in public opinion).Gorus Journal (57), 14-22.

Allen, N. J., \& Meyer, J. P. (1990). The measurement and antecedents of affective, continuance and normative commitment to the organization. Journal of occupational and organizational psychology, 63, 1-18. https://doi.org/10.1111/j.2044-8325.1990.tb00506.x

Allen, N. J., \& Meyer, J. P. (1996). Affective, continuance, and normative commitment to the organization: An examination of construct validity. Journal of vocational behavior, 49(3), 252-276. https://doi.org/10.1006/jvbe.1996.0043

Argon, T. (2016). Öğretmen görüşlerine göre ilkokullarda yöneticilerin kayırmacılık davranışları. (According to teachers' views, favouritiam behaviours of primary school administrators) Kastamonu Education Journal, 24(1), 233-250.

Aydın, Y. (2015). Örgütsel sessizliğin okul yönetiminde kayırmacılık ve öğretmenlerin öz yeterlik algısı ile ilişkisi (The relationship of organizational silence with favoritisim in schoolmanagement and self-efficacy perception of teachers). (Unpublished MA dissertation).Gazi University Institute of Education Sciences, Ankara.

Aydogan, İ. (2008). Favoritism in the classroom: A study on Turkish schools. Journal of Instructional Psychology, 35(2), 159-168.

Aydoğan, İ. (2009). Favoritism in the Turkish educational system: Nepotism,cronyism and patronage. Educational Policy Analysis and Strategic Research, 4(1).

Aydoğan, İ. (2012). The existence of favoritism in organizations.African Journal of Business Management, 6(12), 4577-4588. https://doi.org/10.5897/AJBM11.2692

Aytaç, Ö. (2010a). Kayırmacı ilişkilerin sosyolojik temeli. (Sociological basis of the favouritism relations). Yönetim ve örgüt açısından kayrmacılık(Favouritism in terms of management and organization). (Ed.Ramazan Erdem).İstanbul: Beta Publications.

Aytaç, Ö. (2010b). Bürokratik kayırmacılık: Enformel bağlayıcılıkların yönetim ilişkilerine etkisi.(Bureaucratic Favourtisim: Effect of informal bindings on management relationships). Yönetim ve Örgüt AçısındanKayrmacılık (Favouritism in terms of management and organization)(Editor: Ramazan Erdem). İstanbul: Beta Press.

Aytaç, Ö., \& İlhan, S. (2010). Türkiye'de kayırmacı eğilimlerin oluşmasında toplumsal ve kültürel yapının rolü (Editor: Ramazan Erdem). (The role of social and cultural structure in the formation of favouritism tendencies in Turkey)Yönetim ve Örgüt Açısından Kaylrmacllk. (Favouritism in terms of management and organization) İstanbul: Beta Press.

Bakan, İ. (2011). Örgütsel stratejilerin temeli örgütsel bağlllık kavram, kuram, sebep ve sonuçlar. (The foundation of organizational strategy organizational commitment concept, theory, cause and consequences). Ankara: Gazi Bookshop.

Bakırcı, K. (2000). İşyerinde cinsel taciz ve Türk iş hukukuna ilişkin çözümönerileri. (Sexual harassment in the workplace and suggestions for solutions to Turkish labour law)Retrieved March 3, 2017 from http://www.turkhukuksitesi.com/makale_25.htm 
Bakırcıŏlu, R. (2012). Eğitim ve psikoloji sözlüğ̈̈.(Dictionary of Education and psychology).Ankara: Anı Press.

Balay, R. (2014). Yönetici ve ögretmenlerde örgütsel bağlllik. (Organizational commitment in Administrators and Teachers).Ankara: Pegem Press.

Bayram, L. (2005). Yönetimde yeni bir paradigma: Örgütsel bağll1ık. (A new paradigm in management: Organizational Commitment) Saylstay Dergisi (The Journal of the court of accounts), (59), 125-139.

Becker, T. E., Billings, R. S., Eveleth, D. M., \& Gilbert, N. L. (1996). Foci and bases of employee commitment: Implications for job performance. Academy of Management Journal, 39(2), 464-482.https://doi.org/10.2307/256788

Boylu, Y., Pelit, E., \& Güçer, E. (2007). Akademisyenlerin örgütsel bağlılıkları üzerine bir araştırma. (A research on the organizational commitment of the academicians). Finans Politik ve Ekonomik Yorumlar(Financial, political and economic interpretations), 44(511), 55-74. Retrieved May 17, 2018 from http://www.ekonomikyorumlar.com.tr/files/articles/1528289300.pdf

Bozkurt, Ö., \& Yurt, İ. (2013). Akademisyenlerin örgütsel bağlllık düzeylerini belirlemeye yönelik bir araştırma.(A research aimed at determining the level of organizational commitment of academicians). Yönetim Bilimleri Dergisi (Journal of Management Sciences), 11(22), 121-139.

Büte, M. (2009). Aile İşletmelerinde Nepotizm: Trabzon ilinde faaliyet gösteren aile şirketlerinde nepotizm uygulamasının tespitine yönelik bir araştırma. (Nepotism in family enterprises: A research on the determination of nepotism application in family companies operating in Trabzon province) 17. Ulusalyönetim ve organizasyon kongresi bildiriler kitabl, $\left(17^{\text {th }}\right.$ National Congress of Management and Organization Proceedings book) 737-741. RetrievedFebruary 19, 2019 from (http://w3.balikesir.edu.tr/ seymen/yonetim.pdf).

Büyüköztürk, Ş. (2010). Sosyal bilimler için veri analizi el kitabı. (Data Analysis Manual for Social Sciences).Ankara: Pegem Publishing.

Can, A. (2014). Spss ile bilimsel araştırma sürecinde nicel veri analizi. (Quantitative data analysis in scientific research process with SPSS). Ankara: Pegem Press.

Çelik, K., \& Erdem, A. R. (2012). Üniversitede çalışan idari personele gore kayırmacılık. (According to the administrative staff of running the college, favouritism). (Akdeniz Eğitim Araştırmalarl Dergisi) (Akdeniz Journal of Educational Sciences), 6(11), 23-30.

Chandler, J. L. (2012). Black women's perceptions of the relationship among nepotism, cronyism job satisfaction, and job-focused self-efficacy (Unpublished PhD dissertation), San Francisco University, USA.

Dağlı, A., \& Gençdal, G. (2018). Öğretmenlerin örgütsel bağl1lı̆̆a ilişkin algılarının bazı değişkenlere göre incelenmesi.(Examination of teachers' perceptions of organizational commitment according to some variables).Elektronik Eğitim Bilimleri Dergisi (Electronıc Journal of Educatıon Sclences), 7(14), 164-175.

Dağlı, A., Elçiçek, Z., \& Han, B. (2018). Örgütsel bağlllık ölçeği'nin Türkçeye uyarlanması: Geçerlik ve güvenirlik çalışması. (Adaptation of organizational commitment scale to Turkish: Validity and reliability study).Elektronik Sosyal Bilimler Dergisi, 17(68), 1765-1777.

Demaj, E. (2012). Nepotism, favoritism and cronyism and their effects on organizational trust and commitment: The case of the service sector in Albania (Unpublished PhD dissertation). Epoka University, Arnavutluk.

Dökümbilek, F. (2010). Aile şirketlerinde nepotizm ve bir araştırma. (Nepotism in family companies and a study).(Unpublished MA disertation).Bahçeşehir University, Institute of Social Sciences, İstanbul.

Erdem, M., \& Meriç, E. (2012). Okul yönetiminde kayırmacılı̆ga ilişkin ölçek geliştirme çalışması.(Scale development study in school administration concerning favouritism). Research Journal of Educational Sciences, 2(2), 141-154.

Erdem, R. (2010). Kayırmacılık/ayrımcılık. Yönetim ve örgüt açısından kayırmacılık. (Favouritism/discrimination).(Favouritism in terms of management and organization).(Editor: Ramazan Erdem). İstanbul Beta Press.

Eren, E. (2010). Örgütsel Davranış ve Yönetim Psikolojisi. (Organizational Behaviour and Management Psychology).İstanbul: Beta Press.

Fields, D. L. (2002). Taking the measure of work: A guide to validated scales for organizational research and diagnosis.Sage publications. https://doi.org/10.4135/9781452231143

Garicano, L., Palacios-Huerta, I., \& Prendergast, C. (2005). Favoritism under social pressure. The Review of Economics and Statistics, 87(2), 208-216.https://doi.org/10.1162/0034653053970267

Geçer, A. (2015). Liselerde çalışan öğretmenlerin kayırmacılık ve örgütsel destekalgı düzeyleri. (Favouritism and 
organizational support perception levels of the teachers working in high schools).(Unpublished MA dissertation). Muğla Sttkı Koçman University, Muğla.

Güney, S. (2015). Örgütsel davranıs. (Organizational Behaviour).Ankara: Nobel Publications.

Hooft, E. A., \& Stout, T. (2012). Nepotism and career choice, job search, and job choice.Nepotism in Organizations (Ed. Robert G. Jones). USA.

Kaptan, S. (1991). Bilimsel araştırma ve istatistik teknikleri.(Scientific research and statistics techniques). Ankara: Rehber Publishing

Karademir, M. (2016). Ortaokul öğretmenlerinin okul yönetiminde kayırmacılık algıları ile örgütsel sinizm arasındaki ilişsinin incelenmesi: İstanbul ili pendik ilçesi örneği. (Examining the relationship between the perceptions of favouritism of secondary school teachers and organizational cynisme on school management: The example of Pendik in Istanbul)(Unpublished MA dissertation).Istanbul Aydın University, İstanbul.

Karahan, A., \& Yılmaz, H. (2014). Nepotizm ve örgütsel bağllık arasındaki ilişkinin incelenmesi ve bir uygulama.(Examining the relationship between nepotism and organizational commitment and an application). Social Economic Journal of Research, 14(27), 123-148.https://doi.org/10.30976/susead.302221

Karakaş, M., \& Çak, M. (2007). Yolsuzlukla mücadelede uluslararası kuruluşların rolü.(The role of international organizations in the fight against corruption).The Journal of Finance, (153), 74-101.

Karasar, N. (2006). Bilimsel araştırma yöntemi. (Scientific Research Method).Ankara: Nobel Publications.

Khatri, N., Wen, C. Y., Fuei, L. W., \& Geok, T. A. (2008). Cronyism: antecedents and consequences. Retrieved February 10, 2018 from https://pdfs.semanticscholar.org/11fa/eaf438915decf72b83ed875f05bb331a1656.pdf

Laker, D. R., \& Williams, M. L. (2003). Nepotism's effect on employee satisfaction and organizational commitment: An empirical study.International Journal of Human Resources Development and Management, 3(3), 191-202. https://doi.org/10.1504/IJHRDM.2003.003660

Longman, L. (2004). Longman Dictionary of English Idioms.London: Longman.

Mathieu, J. E., \& Zajac, D. M. (1990). A review and meta-analysis of the antecedents, correlates, and consequences of organizational commitment. Psychological bulletin, 108(2), 171-194.

https://doi.org/10.1037/0033-2909.108.2.171

Meriç, E. (2012). İlköğretim okullarında görev yapan öğretmenlerin algılarına göre okul yönetiminde kayırmacılık. (According to the perceptions of primary school teachers favouritism on school management).(Unpublished MA dissertation).Yüzüncü Yıl University Institute of Social Sciences, Van.

Meriç, E., \& Erdem, M. (2013). İlköğretim okullarında görev yapan öğretmenlerin algılarına göre okul yönetiminde kayırmacilık. (According to the perceptions of primary school teachers favouritism on school management).Education Management in Theory and Practice, 19(3), 467-498.

Moharib, N. I. (2013). Effects of parental favoritism on depression and aggression in Saudi Arabian adolescents.Social Behavior and Personality: An International Journal, 41(9), 1497-1510. https://doi.org/10.2224/sbp.2013.41.9.1497

Muthuveloo, R., \& Rose, R. C. (2005). Typology of organizational commitment.American Journal of Applied Science, 2(6), 1078-1081.https://doi.org/10.3844/ajassp.2005.1078.1081

Nadler, J., \& Schulman, M. (2006). Favoritism, cronyism, and nepotism. http://www.scu.edu/ethics/practicing/focusareas/government_ethics/introduction/cronyism. html

Okçu, V., \& Uçar, A. (2016). Effect of school principals' favoritism behaviors andattitudes on teachers' organizational commitment, based on the perceptions ofprimary and secondary school teachers.Journal of Human Sciences, 13(3), 5901-5914. https://doi.org/10.14687/jhs.v13i3.4304

Ören, K. (2007). Sosyal sermayede güven unsuru ve işgücü performansına etkisi.(Element of trust in social capital and the impact of it on labour performance). Kaтu-ISs, 9(1), 71-90.

Özkalp, E., \& Kırel, Ç. (2013). Örgütsel davranı̧̧ (Organizational Behaviour).Bursa: Ekin Publications.

Özkanan, A., \& Erdem, R. (2014). Yönetimde kayırmacı uygulamalar: Kavramsal bir çerçeve.(Favouritim applications inmanagement: a conceptual framework).Süleyman Demirel University Journal of Social Sciences, 2(20), 179-206.

Özler, H., Ergun-Özler, D., \& Gümüş̧tekin-Eren, G. (2007). Aile isletmelerinde nepotizmin gelişim evreleri ve kurumsallaşma. (Stages of the development of nepotism in family enterprises and institutionalization).Selçuk University Journal of Social sciences Institute, (17), 437-450. 
Özsemerci, K. (2003). Türk Kamu Yönetiminde Yolsuzluklar, Nedenleri, Zararları ve Çözüm Önerileri. (Causes,Damages and Solution Offers for Corruption in Turkish Public Admiistration).T.R. The Court of Accounts/ Research / Review / Translation $\quad$ Series: $27 . \quad$ Retrieved February $19, \quad 2018$ from https://www.sayistay.gov.tr/tr/Upload/95906369/files/yayinlar/TurkKamuYonetiminde_Yolsuzluklar.pdf

Polat, S., \& Kazak, E. (2014). Okul yöneticilerinin kayımacı tutum ve davranışları ile öğretmenlerin örgütsel adalet algıları arasındaki ilişki.(The relationship between favouritism attitudes and behaviours school administrators and teachers' perceptions of organizational justice). Education Management in Theory and Practice, 20(1), 71-92. https://doi.org/10.14527/kuey.2014.004

Pounder, D. G., \& Blase, J. J. (1988). Principal favoritism: Explanations, effects, and implications for practice.Planning and Changing, 19(1), 3-7.

Prendergast, C., \& Topel, R. H. (1996). Favoritism in organizations.Journal of Political Economy, 104(5), 958-978. https://doi.org/10.1086/262048

Prisloo, S. (2006). Sexual harassment and violence in South African schools. South African Journal of Education, 26(2), 305-318.

Ramachander, A. (2011). Dealing with favoritism at the workplace. Retrieved October 12, 2017 from http://www.deccanherald.com/content/173905/dealing-favouritism-workplace.html

Roy, M. H., \& Roy, F. C. (2004). An empirical analysis of favoritism during business training. Industrial and Commercial Training, 36(6), 238-242. https://doi.org/10.1108/00197850410556676

Şalcı, G. (2015). Kayırmacılığın örgütsel bağllı̆ğa etkisi: Mersin ili turizm işletmelerinde bir saha araştırması. (The effect of nepotism on organizational commitment; a field research in tourism businesses of Mersin province). (Unpublished MA dissertation).Toros University, Mersin.

Sezici, E., \& Yıldız, B. (2017). Algılanan örgütsel kronizmin örgütsel bağlllık üzerindeki etkisinde istihdam edilebilirlik algısının aracı rolü.(The mediating role of perceived employability on organizational cronyism and organizational commitment relationship). Kastamonu University Journal of faculty of Economics and Administrative Sciences-, 18(1), 56-74.

Sheridan, M. K. (2007). Just because it's sex doesn't mean it's because of sex: The need for new legislation to target sexual $\begin{array}{llll}\text { favoritism. } & \text { Retrieved } & \text { April, } & \text { from }\end{array}$ https://heinonline.org/HOL/Page?collection=journals\&handle=hein.journals/collsp40\&id=391\&men_tab=srchresults

Tarhan, R. B., Gençkaya, Ö. F., Ergül, E., Özsemerci, K., \& Özbaran, H. (2006). Yolsuzlukla Mücadele-TBMM Raporu.Bir olgu olarak yolsuzluk: Nedenler, etkiler ve çözüm önerileri- (Fight against corruption-Grand National Assembly Report. Corruption as a case: Causes, Effects and Solution Offers). Retrieved February, 21 from https://www.tepav.org.tr/upload/files/1313475413-4.Bir_Olgu_Olarak_Yolsuzluk_Nedenler_Etkiler_Cozum_Oneri leri.pdf[A6]

Taylor, R. (1990). Interpretation of the correlation coefficient: A basic review. Journal of Diagnostic Medical Sonography, 6, 35-9. https://doi.org/10.1177/875647939000600106

Yıldırım, M. (2013). Kamu yönetiminin kadim paradoksu: Nepotizm ve meritokrasi. (Nepotism and merit in public administration). Celal Bayar University Journal of Social Sciences, 11(2), 353-380.

Yılmaz, A., \& Kılavuz, R. (2002). Türk kamu bürokrasisinin işlemsel sorunları üzerine notlar.(Notes on Operational Problems of Turkish Public Bureaucracy) Cumhuriyet University Journal of faculty of Economics and Administrative Sciences, 3(2), 17-31.

Zingales, L. (2012). A Crusader Against Crony Capitalism. Retrieved February 16, 2018 from https://www.independent.co.uk/news/business/analysis-and-features/luigi-zingales-a-crusader-against-crony-capitalis $\mathrm{m}-7869975 . \mathrm{html}$

\section{Copyrights}

Copyright for this article is retained by the author(s), with first publication rights granted to the journal.

This is an open-access article distributed under the terms and conditions of the Creative Commons Attribution license which permits unrestricted use, distribution, and reproduction in any medium, provided the original work is properly cited. 